\title{
Endemik Alyssum discolor'un (Brassicaceae) Tohum Çimlenmesi ve Kök-Gövde Gelişimi Üzerine Nikel, Bakır ve Demir Etkisi
}

\author{
Cennet ÖZAY* \\ Pamukkale Üniversitesi, Fen-Edebiyat Fakültesi, Biyoloji Bölümü, 20070, Denizli, Türkiye
}

Geliş / Received: 15/5/2018, Kabul / Accepted: 21/11/2018

\begin{abstract}
Öz
Bu çalışmada, Brassicaceae familyasından endemik Alyssum discolor tohumlarına farklı konsantrasyonlarda (0.2-5.0 mM) klor tuzu şeklinde uygulanan bazı ağır metallerin ( $\mathrm{Ni}, \mathrm{Cu}$ ve $\mathrm{Fe}$ ) tohum çimlenmesi ve kök-gövde gelişimi üzerindeki etkileri incelendi. Ayrıca A. discolor'un toprak üstü kısmındaki Ni, $\mathrm{Cu}$ ve Fe içerikleri, İndüktif Eşleşmiş Plazma-Optik Emisyon Spektrometrisi (ICP-OES) ile belirlendi. Tohumlar, plastik petriler içerisindeki şişme ortamı sıvısıyla sslatılmış çift katlı kaba filtre kağıtlarının üzerine, her bir petriye 25 'er tohum gelecek şekilde ekildi. Ekimden hemen sonra kapağı kapatılan petriler etüve kaldırıldı ve 72 saat süreyle 23$24^{\circ} \mathrm{C}$ 'de karanlık ortamda çimlenmeye bırakıldı. 72 saat sonunda radikula belirimi esasına göre tohumların çimlenme oranları tespit edildi ve her bir gruptaki çimlenen kök ve gövde uzunlukları ölçüldü. Tohum çimlenmesi, uygulanan ağır metal konsantrasyonlarındaki artışa paralel olarak azalırken, kök ve gövde uzunluklarının ise $\mathrm{Fe}$ hariç $\mathrm{Ni}$ ve $\mathrm{Cu}$ uygulamalarında konsantrasyon artışına bağlı olarak önemli düzeyde $(\mathrm{P}<0.05)$ azaldığı belirlendi. Serpantin özellik göstermeyen bir alandan toplanan $A$. discolor'un içerdiği Ni konsantrasyonu $13.48 \pm 0.44 \mathrm{mg} / \mathrm{kg}$ olarak tespit edildi. A. discolor'un gövde kuru ağırlığının $\mathrm{Ni}$ konsantrasyonu $1000 \mathrm{mg} / \mathrm{kg}$ 'dan daha az olduğu için Ni hiperakümülatörü özelliği göstermediği, bu sebepten dolayı da Ni'den etkilendiği ve tolerans gösteremediği sonucuna ulaşılabilir.
\end{abstract}

Anahtar Kelimeler: Ağır metal, Alyssum discolor, Çimlenme, ICP-OES, Kök-gövde gelişimi

Effect of Nickel, Copper and Iron on Seed Germination and Root-Shoot Growth of Endemic Alyssum discolor (Brassicaceae)

\begin{abstract}
In this study, the effect of some heavy metals $(\mathrm{Ni}, \mathrm{Cu}$ and $\mathrm{Fe})$ in the form of chloride salt at different concentrations (0.2-5.0 mM) on seed germination and root-shoot growth of endemic Alyssum discolor was investigated. Also, $\mathrm{Ni}, \mathrm{Cu}$ and $\mathrm{Fe}$ contents of above-ground parts of $\mathrm{A}$. discolor were determined by Inductively Couple Plasma- cvOptical Emission Spectrometer (ICP-OES). Seeds were sown on the double-layer rough filter papers which were soaked with swelling medium liquid in the plastic petri-dishes, with 25 seeds on each dishes. Immediately after sowing, the petri-dishes were covered and kept into oven to germinate in the dark at 23-24 ${ }^{\circ} \mathrm{C}$ for 72 hours. At the end of 72 hours, the germination rates of seeds were determined on the basis of the emergence of the radicle and root and shoot lengths of the germinated seeds in each group were measured. It was determined that root and shoot lengths decreased significantly $(\mathrm{P}<0.05)$ due to concentration increase in $\mathrm{Ni}$ and $\mathrm{Cu}$ applications except $\mathrm{Fe}$, while seed germination decreased in parallel with the increase in applied heavy metal concentrations. The concentration of Ni that contained in A. discolor collected from a nonserpentine area was found to be $13.48 \pm 0.44 \mathrm{mg} / \mathrm{kg}$. It can be concluded that $A$. discolor does not show Ni hyperaccumulator property as its Ni concentration of the shoot dry weight of A. discolor is less than $1000 \mathrm{mg} / \mathrm{kg}$ and therefore it is affected by $\mathrm{Ni}$ and cannot tolerate it.
\end{abstract}

Keywords: Heavy metal, Alyssum discolor, Germination, ICP-OES, Root-shoot growth

\section{Giriș}

Gelişmiş ve gelişmekte olan ülkelerde sanayi ve teknolojik nedenlerle bazı metallerin üretimi artış gösterirken buna bağlı olarak da tüketimin hızla artması bunların çevreye yayılması olasılığını arttırmakta ve ekosistemi 
geri dönüşümsüz bir duruma getirmektedir. Günümüzde toprakta ağır metal kirliliği önemli çevresel problemlerden birisidir. Ağır metallerin toprakta aşırı birikmesinin sadece toprak verimliliği ve ekosistem fonksiyonları üzerinde değil aynı zamanda besin zinciri yoluyla havyan ve insan sağlığı üzerinde de önemli etkileri vardır (Munzuroğlu ve Geçkil, 2002). Ağır metallerin, özellikle belirli dozlardan itibaren bitkilerdeki fizyolojik fonksiyonları ve biyokimyasal olayları doğrudan veya dolaylı olarak etkilediği bilinmektedir. Bitki dokularında ağır metal birikimi tolerans düzeyini aştığında mineral besin alım1, transpirasyon, fotosentez, enzim aktivitesi (Nussbaum vd., 1988), nükleik asit yapıs1, klorofil biyosentezi ve çimlenme (Munzuroğlu ve Geçkil, 2002) gibi çok sayıda fizyolojik ve biyokimyasal aktivite olumsuz yönde etkilenir. Ağır metaller arasında yer alan $\mathrm{Mn}, \mathrm{Fe}, \mathrm{Cu}, \mathrm{Zn}$ ve $\mathrm{Ni}$ gibi elementler yüksek bitkiler icin esas (temel, esansiyel) elementlerdir. Bitki için gerekli olsun ya da olmasın ağır metallerin doku ve organlardaki aşırı birikimi toksik etki yapmakta ve sonunda bitkiyi ölüme götürmektedir. (Mengel vd., 2001). Bitkilerin ağır metal toksisitesine karşı toleransları bitki türüne, element türüne, strese maruz kalma süresine ve strese maruz kalan doku veya organın yapısına bağlı olarak değişmektedir. Bu nedenle ağır metalin tür ve miktarı, yarayışlılığı, zararın şiddeti ve türü ayrıca zarar oluşum sürecinin bilinmesi bitkilerin gelişimi ve canlılığı açısından oldukça önemlidir (Cunningham ve Ow, 1996). Tohum çimlenmesi ve fide gelişimi aşamasında metallere karşı verilen tepkilerle ilgili olarak türler içinde veya türler arasında varyasyonların olduğu vurgulanmaktadır. Yapılan birçok çalışmayla ağır metal stresinin bitki türüne göre farklı derecede etki gösterdiği ve bunun da bitki türünün sahip olduğu tolerans mekanizmalarıyla alakalı olduğu anlaşılmaktadır. Metal toleransh bitkilerin ve hiperakümülatör türlerin tohumlarında toksisite eşik değeri toleranslı olmayan türlerin eşik değerinden daha yüksektir. Genel olarak her bir ağır metalin türler üzerindeki toksik etkisi ve türün her bir metale karşı göstereceği tolerans seviyesi farklıdır (Kranner ve Colville, 2011).

Ülkemiz, farklı iklim ve ekolojik koşullara sahip olması, floranın çok sayıda bitki türü ve çeşitliliği içermesi bakımından oldukça zengindir ve dünyanın sayılı ülkeleri arasında yer almaktadır (Güner vd., 2012). Türkiye florası, sahip olduğu tür zenginliğinin yanında içerdiği endemik bitki sayısı bakımından da çok zengindir. Brassicaceae familyası Alyssum, Crambe, Sinapis, Thlaspi ve Brassica başta olmak üzere pek çok cinsi barındırmaktadır (Cartea vd., 2010). Türkiye Florası'nın büyük cinsleri arasında yer alan Alyssum L. cinsinin yapılan son revizyonlarla birlikte ülkemizde 110 taksona sahip olduğu ve bunların da 50 kadarının endemik olduğu bilinmektedir (Şahin ve Şimşek, 2016). Alyssum cinsine genel olarak "kevke" denilmektedir (Baytop, 2007). Hercai kevke olarak bilinen endemik Alyssum discolor T.R. Dudley \& Hub.-Mor., VU (Vulnerable - Zarar görebilir) tehlike kategorisinde yer almaktadır (Güner vd., 2012; IUCN, Ver. 3.1, 2001). Alyssum türlerinin çoğu kuru yapraklarında $1000 \mu \mathrm{g} / \mathrm{g} \quad(\% 0,1)$ 'dan fazla nikel (Ni) biriktirme kapasitesine sahip olduğundan dolayı Ni hiperakümülatörü olarak bilinmektedir (Adıgüzel ve Reeves, 2012). Oldukça fazla varyasyon gösteren Alyssum türleri, özellikle Odontarrhena (Meyer) Hooker seksiyonunda, serpantin bölgelerde, ultramafik (volkanik) kaya ve topraklarda yetişmektedir (Davis, 1965). Odontarrhena seksiyonunda yer alan A. discolor, hem serpantin topraklarda hem de normal topraklarda yetişebilen bir türdür (Reeves ve Adiguzel, 2004). Bu çalışmada serpantin özellik göstermeyen topraklarda yetişen $A$. discolor'da nikel, bakır ve demir uygulamalarının tohum çimlenmesi ve kökgövde gelişimini ne ölçüde etkiledikleri araştırılmıştır. 


\section{Materyal ve Method}

\subsection{Bitki materyali}

Dünyada Alyssum cinsi içerisinde 210 kadar geçerli tür vardır. Bu 210 türden 110 kadarı Türkiye'de yaşamaktadır. Alyssum cinsinin dünyadaki gen merkezi tartışmasız bir şekilde Doğu Akdeniz ve Türkiye'dir (Şahin ve Şimşek, 2016). Alyssum cinsi Türkiye Florası'na (Dudley, 1965) göre beş seksiyona ayrilmaktadır. Bu seksiyonlar şu şekildedir: Meniocus (Desv.) Hooker, Psilonema (Meyer) Hooker, Alyssum, Gamosepalum (Hausskn.) Dudley, Odontarrhena (Meyer) Hooker. Batı ve Güney Anadolu'da yayılış gösteren endemik (VU, IUCN, ver 3.1, 2001) A. discolor, Odontarrhena seksiyonunda yer almaktadır (Reeves ve Adiguzel, 2004). Bitki, çok yıllık, çalı formunda olup Doğu Akdeniz elementidir. Fertil gövdenin uzunluğu 25 cm.'nin üzerinde, petaller 3.5-4 mm, silikula tipinde olan meyveler ise buruşuk ve saplıdır. Nisan-Mayıs aylarında çiçeklenen A. discolor, yaşam alanı olarak kireçtaşı, kumtaşı ve serpantin bölgeleri tercih etmektedir (Davis, 1965). A. discolor, 15 Haziran 2015 tarihinde Pamukkale Üniversitesi (Denizli) Kampüsü, Mediko Sosyal Merkezi yanındaki serpantin özellik göstermeyen çayırlık alandan (500 m.) toplandıktan sonra, Prof. Dr. Olcay Düşen (Pamukkale Üniv., Biyoloji Böl.) tarafından teşhis edilmiştir. Bitkiden çıkarılan tohumlara Tetrazolium (TZ) testi uygulanmış ve boyanan tohumlar canlı olarak kabul edilmiştir. Bitkinin toprak üstü kısımları ise gölge ve hava akımının bulunduğu bir ortamda 1 hafta boyunca kurutulduktan sonra ticari blender ile parçalanmıştır.

\section{2. Ăğır metal miktarlarının belirlenmesi}

\subsubsection{Bitki örneğinin analize hazırlanması}

Çalışmada, Milestone Start D cihazında bitki numunesi yakılmıştır. Mikro dalga kaplarına, homojenize edilmiş numuneden $0,5 \mathrm{~g}$ alınmış, üzerine $9 \mathrm{~mL} 10 \mathrm{M} \mathrm{HNO}_{3}$ ve $3 \mathrm{~mL} 10 \mathrm{M} \mathrm{HCl}$ eklenmiştir (EPA 3051A, 1998). Yakma işlemine ait iki aşamalı sıcaklık programı şu şekildedir: İlk aşamada, 15 dakikada mikrodalga cihazının sicaklığ $110^{\circ} \mathrm{C}^{\prime}$ ye çıkarılmıştır. İkinci aşamada, $110^{\circ} \mathrm{C}$ 'lik sıcaklıkta 15 dakika beklenmiştir. Cihaz soğuduktan sonra örnek alınmış ve İndüktif Eşleşmiş Plazma-Optik Emisyon Spektrometrisi'nde (ICP-OES) okumalar yapılmıştır. Homojenize edilmiş numuneden üç paralel çalışılmıştır. Çalışmada kullanılan nitrik asit (\% 65) ve hidroklorik asit (\% 37) Sigma Aldrich firmasından temin edilmiştir. Analizi yapılan ağır metaller $(\mathrm{Ni}, \mathrm{Cu}, \mathrm{Fe})$ ise VHG firmasından alınmıştır.

\subsubsection{Kullanılan cihaz ve çalışma şartlart}

Perkin Elmer Optima-8000 cihazında gerçekleştirilen çalışmada yer alan ağır metaller için seçilen dalga boyları, Tablo 1'de gösterilmiştir. Her bir metal için derişime karşı cihazdan elde edilen şiddet değerlerine karşı çizilen kalibrasyon grafiklerinden elde edilen değerler kullanılarak kantitatif analiz gerçekleştirilmiştir. Geri kazanma deneyleri, çalışılan metallerin bilinen farklı miktarlarının bitkiye işlem görmeden önce katılıp, örnek hazırlama işleminin aynı şekilde uygulanmasıyla yapılmıştır.

\subsection{2. Çimlenme deneyleri}

Çimlenme deneyleri, $23-24^{\circ} \mathrm{C}^{\prime} \mathrm{ye}$ ayarlı etüvde yapılmıştır. İlk olarak, dolgun görünüşlü, sağlam ve birbirine benzer büyüklükte yeterli sayıda tohum seçilmiştir. Ağır metal olarak nikel $\left(\mathrm{Ni}^{+2}\right)$, bakır $\left(\mathrm{Cu}^{+2}\right)$ ve demir $\left(\mathrm{Fe}^{+2}\right)^{\prime}$ in klor tuzlar1 $\left(\mathrm{NiCl}_{2} \cdot 6 \mathrm{H}_{2} \mathrm{O}\right.$, $\mathrm{CuCI}_{2} .2 \mathrm{H}_{2} \mathrm{O}$ ve $\left.\mathrm{FeCI}_{2} .4 \mathrm{H}_{2} \mathrm{O}\right)$ kullanılmıştır. Tohumlar, yüzey sterilizasyonu için \%10'luk sodyum hipoklorit $(\mathrm{NaOCl})$ çözeltisi ile 15 dakika muamele edilmiş ve daha sonra distile su ile en az 3 kere yıkanarak farklı konsantrasyonlarda (0.2-5.0 mM) hazırlanan ağır metal çözeltilerinde, kontrol grubu ise distile su içerisinde 6 saat süre ile şişirilmiştir. $\mathrm{Bu}$ süre sonunda şişme ortamından alınan tohumlardan, 9 cm'lik plastik petriler içerisindeki $5 \mathrm{~mL}$ şişme ortamı sıvısıyla 1slatılmış çift katlı filtre kağıtlarının üzerine, 
her bir petriye 25 'er tohum gelecek şekilde ekim yapılmıştır. Her bir seri 3 tekrarlı olarak yürütülmüştür. Ekimden hemen sonra kapağ 1 kapatılan petriler $23-24^{\circ} \mathrm{C}$ 'deki etüvde, karanlık ortamda 72 saat süreyle çimlenmeye bırakılmıştır. Radikula belirimi esasına göre tohumların çimlenme oranları 72 saat sonunda tespit edilmiştir. Ayrıca süre sonunda her bir gruptaki tohumların kök ve gövde uzunlukları da ölçülerek kaydedilmiştir.

\section{3. İstatistiksel değerlendirme}

Elde edilen veriler, SPSS 17.0 programında Oneway ANOVA Tukey HSD çoklu karşılaştırma testi ile istatistiksel açıdan değerlendirilmiş ve $\mathrm{p}<0.05$ önemli düzey olarak kabul edilmiştir.

\section{Bulgular ve Tartışma}

\subsection{ICP-OES Analizleri}

A. discolor'un içerdiği Ni, $\mathrm{Cu}$ ve Fe miktarları $\mathrm{mg} / \mathrm{kg}$ cinsinden belirlenmiştir. Elde edilen kalibrasyona ait korelasyon katsayısı $\left(\mathrm{R}^{2}\right)$, dedeksiyon limiti (LOD), kantitasyon limiti (LOQ) ve geri kazanım (R, \%) değerleri, Tablo 1'de verilmiştir. Tablo 2'de ağır metallere ait değerler ve bu değerlere ait standart sapmalar gösterilmiştir. $\mathrm{Fe}, A$. discolor'da $316.73 \pm 8.85 \mathrm{mg} / \mathrm{kg}$ iken $\mathrm{Ni}$ ise $13.48 \pm 0.44 \mathrm{mg} / \mathrm{kg}$ olarak tespit edilmiştir.

Tablo 1. ICP-OES analizindeki ağır metaller için seçilen dalga boyları, korelasyon katsayısı $\left(\mathrm{R}^{2}\right)$, dedeksiyon limiti (LOD), kantitasyon limiti (LOQ) ve geri kazanım ( $\mathrm{R}, \%$ ) değerleri.

\begin{tabular}{|l|l|l|l|l|l|}
\hline Ăğr metal & Dalga boyu (nm) & $\mathbf{R}^{\mathbf{2}}$ & LOD $(\mathbf{m g} / \mathbf{k g})$ & LOQ $(\mathbf{m g} / \mathbf{k g})$ & $\mathbf{R}, \boldsymbol{\%}$ \\
\hline $\mathrm{Ni}$ & 231.6 & 0.999 & 0.0003 & 0.001 & 98 \\
\hline $\mathrm{Cu}$ & 324.7 & 0.999 & 0.0009 & 0.003 & 97 \\
\hline $\mathrm{Fe}$ & 259.9 & 0.999 & 0.0006 & 0.002 & 99 \\
\hline
\end{tabular}

Tablo 2. Alyssum discolor'da belirlenen Ni, Cu ve Fe miktarları (mg/kg) ve standart sapma değerleri

\begin{tabular}{|c|c|}
\hline Ăğı metaller & Ăğır metal miktarı (mg/ $\mathbf{k g})$ \\
\hline $\mathrm{Ni}$ & $13.48 \pm 0.44$ \\
\hline $\mathrm{Cu}$ & $24.37 \pm 0.97$ \\
\hline $\mathrm{Fe}$ & $316.73 \pm 8.85$ \\
\hline
\end{tabular}

\subsection{Tohum Çimlenmesi}

Yüksek yapılı bitkilerin yaşam döngüsü içerisindeki en önemli aşamalardan bir tanesi, yeni döllerin sürekliliğini sağlayan tohum çimlenme aşamasıdır. Dinlenme periyodundan sonra, uygun şartlar sağlandığında tohum depo maddeleri çimlenme sürecinde kullanılır ve fide gelişmesi ile yeni bir bitki meydana gelir (Kuriakose ve Prasad, 2008). Bitkiler tohum çimlenmesi ve erken fide gelişimi döneminde değişen çevre koşullarına karşı son derece duyarlı olup zarar gördüğü takdirde bitki yaşam döngüsü daha başlamadan sona erebilmektedir (Kranner ve Colville, 2011). $\mathrm{Bu}$ nedenle, bitkilerin ağır metallere toleransını belirlemede çimlenme ve erken fide gelişimi ile ilgili özellikler sonuca kısa zamanda ulaşılması, basitliği ve düşük maliyetinden dolayı yaygın olarak kullanılmaktadır (Siddiqui vd., 2011). A. discolor tohumlarının $\mathrm{Ni}, \mathrm{Cu}$ ve Fe'in farklı konsantrasyonlarında $(0.2-5.0 \mathrm{mM})$ belirlenen çimlenme yüzdeleri (\%) Şekil 1'de verilmiştir. Tüm gruplarda en yüksek çimlenme yüzdesi kontrol grubunda gözlenirken, $1 \mathrm{mM}, 3 \mathrm{mM}$ ve $5 \mathrm{mM}$ ağır metal uygulamaları ile kontrol arasındaki fark anlamlı $(\mathrm{p}<0.05)$ bulunmuştur. En düşük çimlenme yüzdesi $5 \mathrm{mM} \mathrm{Ni}$ 
uygulamasında görülürken, Ni'in kontrol grubuna göre çimlenmeyi \%58.6 oranında düşürdüğü tespit edilmiştir. $\mathrm{Fe}$, en yüksek konsantrasyonda çimlenmeyi $\% 43.1, \mathrm{Cu}$ ise \%50.0 oranında engellemiştir yani Fe'in toksisite eşik değeri $\mathrm{Ni}$ ve $\mathrm{Cu}$ 'a göre yüksektir. $\mathrm{Bu}$ sonuç bize $A$. discolor tohumlarının Fe'ye olan toleransinı göstermektedir. Ağır metal stresine maruz bırakılan bitki türlerinin farklı çimlenme tepkileri vermeleri, tohum kabuklarının ağır metalleri farklı oranlarda tohum içine geçirmeleri şeklinde açıklanmıştır ( $\mathrm{Li}$ vd., 2005). Çimlenmeyi etkileme oranları bakımından uygulanan ağır metaller çoktan aza doğru $\mathrm{Ni}>\mathrm{Cu}>\mathrm{Fe}$ şeklinde sıralanmıştır. Ağır metalerin tohum çimlenme sürecini negatif yönde etkilediği Brassicaceae familyasından olan Sinapis alba ve Raphanus sativus'da gösterilmişir (Wierzbicka ve Obidzińska, 1998). Bakırca zengin topraklardan toplanan Minuartia hirsuta ve Silene compacta ile $\mathrm{Zn}$ ve $\mathrm{Pb}$ bakımından zengin topraklardan toplanan Alyssum montanum ve Thlaspi ochroleucum'un tohumları kullanılarak bakırın çimlenme ve fide gelişimi üzerindeki etkisi incelenmiştir. Bakırca zengin topraklarda yaşayabilen bitkiler ( $M$. hirsuta ve $S$. compacta), bakıra toleransları sebebiyle $A$. compactum ve $T$. ochroleucum'a göre tohum çimlenmesinden daha az etkilenmişlerdir. Bakır, $S$. compacta'da çimlenmeyi kontrole göre $\% 16$ oranında azaltırken, bu oran $A$. compactum'da \%30 olarak tespit edilmiştir (Ouzounidou, 1995). Yüksek miktarda $\mathrm{Zn}, \mathrm{Pb}$ ve $\mathrm{Cd}$ içeren kalamin toprakta yetişen Alyssum montanum ve Biscutella laevigata (Brassicaceae)'dan toplanan tohumlarla laboratuvar ortamında iki farklı ortam sağlanarak çimlenme yetenekleri incelenmiştir. A. montanum ve $B$. laevigata'nın kalamin içeren ortamda, normal ortama göre daha yüksek çimlenme yeteneği gösterdikleri saptanmıştır. Ayrıca $A$. montanum'da tohumlardan elde edilen fide sayısının (kalamin ortamında) diğer ortama göre 5-7 kat daha fazla olduğu gözlenmiştir.
$\mathrm{Bu}$ sonuç bize ağır metalle kirlenmiş toprakların temizlenmesinde $A$. montanum'un kullanılabilirliğini göstermektedir (Muszyńska vd., 2013).

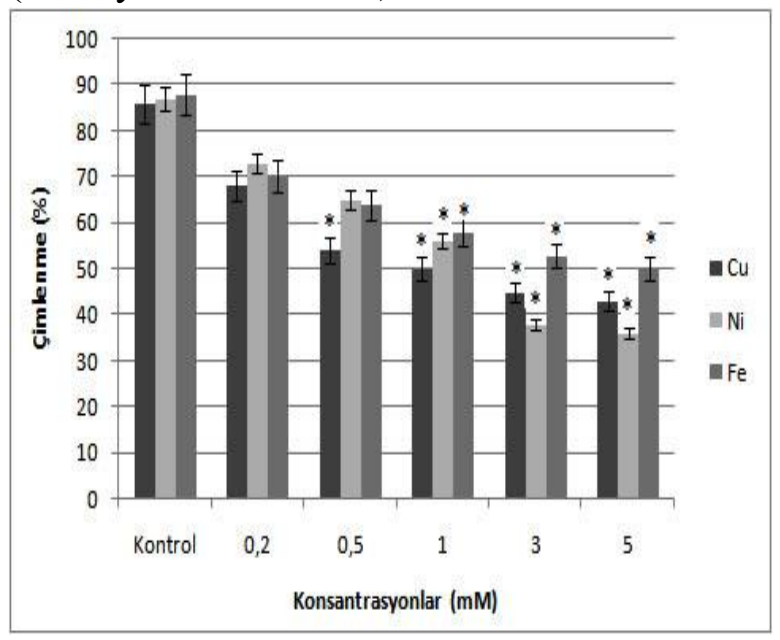

Şekil 1. Alyssum discolor tohumlarının $\mathrm{Ni}, \mathrm{Cu}$ ve $\mathrm{Fe}$ 'in farklı konsantrasyonlarında belirlenen çimlenme yüzdeleri. * Ortalamalar arasındaki fark 0.05 seviyesinde önemli.

\subsection{Kök-Gövde Gelişimi}

Uygulanan metal serilerine göre tohumlarda saptanan kök uzunluğu ( $\mathrm{mm}$ ), gövde uzunluğu (mm) ve kök/gövde oranı sırasıyla Şekil 2, 3 ve 4'de gösterilmiştir. Cu ve Ni'de ölçülen kök ve gövde uzunlukları ağır metal konsantrasyonunun artışına bağlı olarak önemli düzeyde $(\mathrm{P}<0.05)$ azalmıştır. Fe'ye maruz kalan tohumlarda $0.2 \mathrm{mM}$ ve $0.5 \mathrm{mM}$ konsantrasyonlarda kontrole göre daha yüksek kök ve gövde gelişimi meydana gelmiştir. Bu durum A. discolor türünün Fe'yi toprak üstü organlarına taşıyabilmek için kök ve gövdesini geliştirdiğini düşündürmektedir. 1-5 mM Fe uygulaması ise kök ve gövde uzunluğunun azalmasina neden olmuştur $(\mathrm{P}<0.05) . \mathrm{Cu}$ uygulamasinda kontrol grubu kök uzunluğu $6.30 \pm 0.64 \mathrm{~mm}$ iken $5 \mathrm{mM}$ Cu'da kök uzunluğu $0.09 \pm 0.15$ mm'ye düşmüştür. Yani $5 \mathrm{mM} \mathrm{Cu}$ uygulaması kök uzunluğunu \% 98.5 oranında azaltmıştır. Kök/gövde oranında tüm metaller için en yüksek ortalama değer kontrol gruplarında hesaplanırken, en düşük ortalama değer ise 5 $\mathrm{mM} \mathrm{Cu}$ grubunda $(0.45 \pm 0.25)$ hesaplanmıştır. Tüm uygulamalarda kök/gövde oranı 
konsantrasyon artışı ile birlikte azalmıştır. Fidenin kalitesi, sağlıklı bitki yetişmesinde önemlidir. Kök/gövde ilişkisi de bu yönde değerlendirilen kriterlerden bir tanesidir (Tsakaladimi vd., 2013). Gövde kuru ağırlığında $1000 \mathrm{mg} / \mathrm{kg}^{\prime}$ dan daha fazla $\mathrm{Cu}, \mathrm{Co}$, $\mathrm{Cr}$, Ni ve $\mathrm{Pb}$ ya da $10.000 \mathrm{mg} / \mathrm{kg}$ 'dan daha fazla Fe, Mn ve $\mathrm{Zn}$ depo edebilen bitkiler, yüksek seviyede metal biriktirici (hiperakümükatör) olarak tanımlanmaktadır (Baker ve Brooks, 1989; Market, 2003). Hiperakümülatör bitkiler ağır metalleri herhangi bir toksisite semptomu göstermeksizin toprak üstü organlarında diğer bitki türlerine göre 100 ila 1000 kat daha fazla biriktirebilmektedir (Brooks, 1998). Alyssum L. cinsinin bazı türleri nikel metalini kuru yaprak biyokütlesinin \%3'üne varan derişimlerde biriktirme özelliğine sahip hiperakümülatör türlerdir. $\mathrm{Bu}$ özellik, bazı Alyssum türlerinin fitoremediasyonda kullanımına olanak sağlamaktadır (Aydın, 2011; Singer vd., 2007). Türkiye Florası'nda (Dudley, 1965) beş seksiyonda incelenen Alyssum cinsi genellikle serpantin bölgelerde, ultramafik kaya ve topraklarda yetişmektedir (Davis, 1965). Hem serpantin topraklarda hem de normal topraklarda yetişebilen $A$. discolor ise alışılmadık bir $\mathrm{Ni}$ hiperakümülatörüdür (Reeves ve Adiguzel, 2004). Yapılan bir çalışmada, serpantin topraklardan toplanan, Ni-hiperakümülatörü olan A. serpyllifolium ssp. lusitanicum ve A. murale tohumlarına artan konsantrasyonlarda Ni uygulanmış ve bunun sonucunda fidelerde ve çimlenmeyen tohumlarda tespit edilen nikelin artan konsantrasyonla birlikte arttığ1 gözlemlenmiştir. Ni-hiperakümülatörü olmayan A. saxatile L. var. compactum'da ise bu artış diğer iki türe göre oldukça azdır. $A$. serpyllifolium ve A.murale'de $\mathrm{Ni}$ gövdede daha çok biriktirilirken, A. saxatile'de köklerde daha fazla Ni birikimi olmuştur. $A$. serpyllifolium ve A.murale'de çimlenme nikelden etkilenmezken, $A$. saxatile'de artan $\mathrm{Ni}$ konsantrasyonuna bağlı bir azalma meydana gelmiştir (Ghaderian vd., 2000).

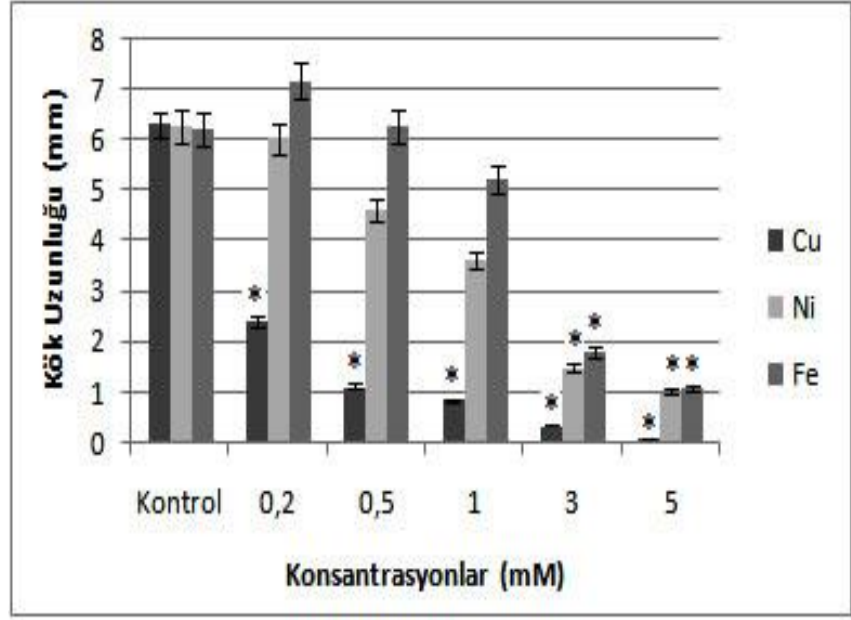

Şekil 2. Alyssum discolor tohumlarının $\mathrm{Ni}, \mathrm{Cu}$ ve Fe'in farklı konsantrasyonlarında belirlenen kök uzunlukları (mm). * Ortalamalar arasındaki fark 0.05 seviyesinde önemli.

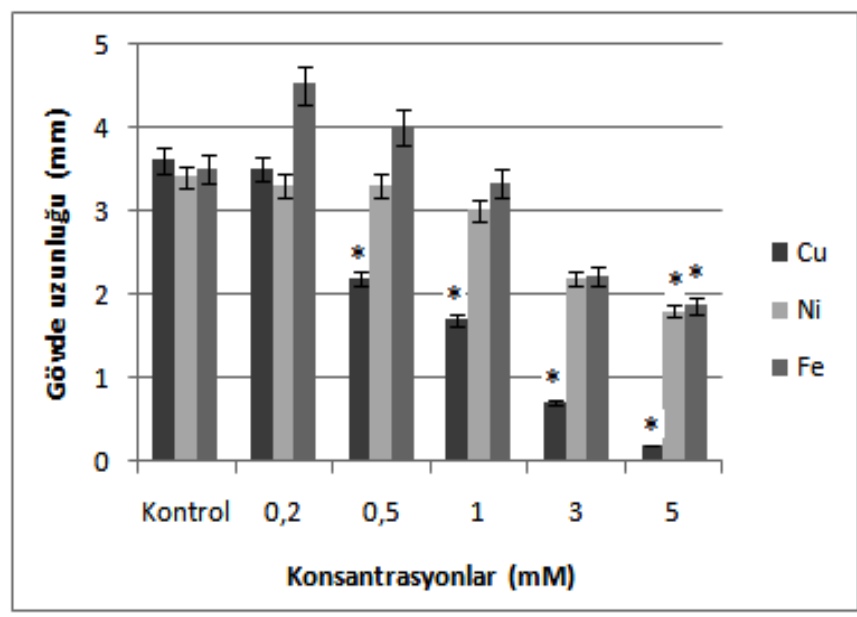

Şekil 3. Alyssum discolor tohumlarının $\mathrm{Ni}, \mathrm{Cu}$ ve $\mathrm{Fe}$ 'in farklı konsantrasyonlarında belirlenen gövde uzunlukları (mm). * Ortalamalar arasındaki fark 0.05 seviyesinde önemli.

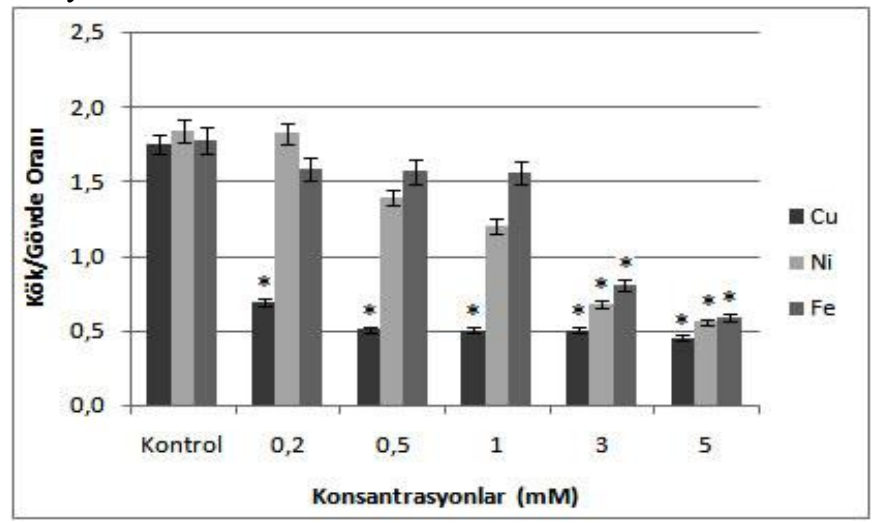

Şekil 4. Alyssum discolor tohumlarının $\mathrm{Ni}, \mathrm{Cu}$ ve Fe'in farklı konsantrasyonlarında belirlenen kök/gövde oranları. * Ortalamalar arasındaki fark 0.05 seviyesinde önemli. 


\section{Sonuç}

Serpantin özellik göstermeyen toprağa sahip bir alandan topladığımız A. discolor'un gövde kuru ağırlığında içerdiği Ni miktarı 1000 $\mathrm{mg} / \mathrm{kg}^{\prime}$ dan daha az olduğu için hiperakümülatör özellik göstermediği, bu sebepten dolayı da Ni'den etkilendiği ve tolerans gösteremediği sonucuna ulaşılabilir.

\section{Teşekkür}

ICP-OES analizlerinin yapılmasını sağlayan Mehmet Akif Ersoy Üniversitesi Bilimsel ve Teknoloji Uygulama ve Araştırma Merkezi Müdürlügü’ne teşekkür ederiz.

\section{Kaynaklar}

Adigüzel N., Reeves R.D. 2012. Important Serpentine Areas Of Turkey And Distribution Patterns of Serpentine Endemics And Nickel Accumulators. Bocconea, 24, 7-17.

Aydin F. 2011. Alyssum corsicum Duby (Brassicaceae) Türünde Nikel ve Kadmiyum Birikimleri ve Moleküler Analizler. Yüksek Lisans Tezi, Gazi Üniversitesi, 90 s.

Baker A.J.M., Brooks R.R. 1989. Terrestrial Higher Plants Which Hyperaccumulate Metallic Elements-A Review of Their Distribution, Ecology and Phytochemistry. Biorecovery, 1, 81126.

Baytop T. 2007. Türkçe Bitki Adları Sözlüğü. Türk Dil Kurumu Yayınları, No 578: 3. Bask1.

Brooks R.R. 1998. General Introduction. In: Brooks, R.R. (ed.). Plants that hyperaccumulate heavy metals: their role in phytoremediation, microbiology, archaeology, mineral exploration and phytomining. CAB International, New York, pp. 1-14.
Cartea M.E., Francisco M., Soengas P., Velasco P. 2010. Phenolic compounds in Brassica vegetables. Molecules, 16, 251-80.

Cunningham S.D., Ow D.W. 1996. Promises and prospects of phytoremediation. Plant Physiology, 110, 715-719.

Davis P.H. 1965. Flora of Turkey and Aegean Islands, Edinburg Univ. Press, Edinburg, 1, 362-409.

Dudley T.R. 1965. Alyssum L. in "Flora of Turkey and the East Aegean Islands", Ed.: Davis, P. H., Edinburgh: Edinburgh University Press., 1: 362-409.

Ghaderian Y.S.M., Lyon A.J.E., Baker A.J.M. 2000. Seedling Mortality of Metal Hyperaccumulator Plants Resulting from Damping off by Pythium spp. New Phytologist, 146(2), 219-224.

Güner A., Aslan S., Ekim T., Vural M., Babaç M.T. (Edlr) 2012. Türkiye Bitkileri Listesi (Damarlı Bitkiler). Nezahat Gökyiğit Botanik Bahçesi ve Flora Araştırmaları Derneği Yayını, İstanbul.

IUCN. 2001. IUCN, Red List Categories: Version 3.1. Prepared By The IUCN Species Survival Commission, IUCN, Gland, Switzerland and Cambridge, UK.

Kranner I., Colville L. 2011. Metals and seeds: Biochemical and molecular implications and their significance for seed germination. Environmental and Experimental Botany, 72, 93-105.

Kuriakose S.V., Prasad M.N.V. 2008. Cadmium stres affects seed germination and seedling growth in Sorghum bicolor (L.) Moench by changing the activities of hydrolyzing enzymes. Plant Growth Regulation, 54, 143-156.

Li W.Q., Khan M.A., Yamaguchi S., Kamiya Y. 2005. Effects of heavy metals on 
seed germination and early seedling growth of Arabidopsis thaliana. Plant Growth Regulation, 46, 45-50.

Market B. 2003. Element concentration in ecosystems. International Institute of Advanced Ecological and Economic Studies, Zittau, Germany.

Mengel K., Kirkby E.A., Kosegarten H., Appel T. 2001. Principles of Plant Nutrition, Dordrecht: Kluwer Academic.

Munzuroğlu O., Geçkil H. 2002. Effects of metals on seed germination, root elongation, and coleoptile and hypocotyl growth in Triticum aestivum and Cucumis sativus. Archives of Environmental Contamination and Toxicology, 43, 203-213.

Muszyńska E., Hanus-Fajerska E., Ciarkowska K. 2013. Evaluation of Seed Germination Ability of Native Calamine Plant Species on Different Substrata. Polish Journal of Environmental Studies, 22(6), 17751780.

Nussbaum S., Shemutz D., Brunold C. 1988. Regulation of assimilatory sulfate reduction by cadmium Zea mays $\mathrm{L}$. Plant Physiology, 88, 1407.

Ouzounidou G. 1995. Effect of copper on germination and seedling growth of Minuartia, Silene, Alyssum and Thlaspi. Biologia Plantarum, 37(3), 411-416.

Reeves R.D., Adiguzel N. 2004. Rare plants and nickel accumulators from Turkish serpentine soils, with special reference to Centaurea species. Turkish Journal of Botany, 28, 147-153.

Siddiqui A.H., Tabrez S., Ahmad M. 2011. Validation of plant based bioassays for the toxicity testing of Indian waters.
Environmental Monitoring and Assessment, 179, 241-253.

Singer A.C., Bell T., Heywood C.A., Smith J.A., Thompson I.P. 2007. Phytoremediation of mixedcontaminated soil using the hyperaccumulator plant Alyssum lesbiacum: evidence of histidine as a measure of phytoextractable nickel. Environmental Pollution, 147(1), 74-82.

Şahin B., Şimşek Ö. 2016. Nezaket Kevkesi (Alyssum nezaketiae) Tür Eylem Planı. Orman ve Su İşleri Bakanlığı, Doğa Koruma ve Milli Parklar Genel Müdürlüğü, Ankara.

Tsakaladimi M., Ganatsas P., Jacobs D.F. 2013. Prediction of planted seedling survival of five Mediterranean species based on initial seedling morphology. New Forests, 44, 327-339.

US Environmental Protection Agency (EPA) Method 3051A. 1998. Microwave assisted acid digestion of sediments, sludges, soils, and oils.

Wierzbicka M., Obidzińska J. 1998. The effect of lead on seed imbibition and germination in different plant species. Plant Science, 137, 155-171. 